\title{
Authoritarian Durability: Public Opinion towards Democracy in Southeast Asia
}

\section{Juliet Pietsch}

To cite this article: Juliet Pietsch (2015) Authoritarian Durability: Public Opinion towards Democracy in Southeast Asia, Journal of Elections, Public Opinion and Parties, 25:1, 31-46, DOI: 10.1080/17457289.2014.933836

To link to this article: http://dx.doi.org/10.1080/17457289.2014.933836

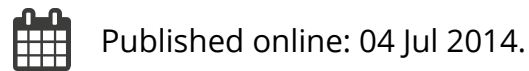

Submit your article to this journal

II Article views: 150

Q View related articles 5

View Crossmark data ¿ᄌ

Citing articles: 2 View citing articles ¿ð 


\title{
Authoritarian Durability: Public Opinion towards Democracy in Southeast Asia ${ }^{\dagger}$
}

\author{
JULIET PIETSCH \\ School of Politics and International Relations, Australian National University
}

\begin{abstract}
This article explores the extent of authoritarian durability and public opinion towards democracy in Southeast Asia drawing on findings from the Asian Barometer. While Freedom House indicators rank many countries in the region as not free or partially free, a high proportion of citizens within the same countries report that they live in a democracy. Conversely, countries ranked as electoral or liberal democracies have high proportions of citizens who report that they do not live in a democracy. These findings reveal quasi-thermostatic concerns that, when satisfied, open the way for the expression of other concerns. Views about democratic experience reveal differing expectations about democracy among the general public. In general, the results suggest that a high proportion of citizens in Southeast Asia have a rather instrumental view of democracy that is underpinned by perceptions of good governance rather than democratic ideals. Still, while economic growth is considered to be very important, when looking at what matters for a functioning democracy, other measures of good governance such as freedom and equality, trust in government, accountability and responsiveness are considered more important.
\end{abstract}

The widespread protest activity across Indonesia in 1998, which led to the abrupt fall of President Suharto and his corrupt New Order regime, revealed the fragile nature of authoritarian regimes in Southeast Asia. Across the border in Malaysia, calls for free and fair elections by the Pakatan Rakyat are symptomatic of a region with growing demands for democracy. But are protests across Southeast Asia representative of broader societal interests there? It is still unclear whether democracy will eventually flourish in a region largely dominated by electoral and competitive authoritarian political systems, which rely on patronage, strong state institutions, control of the media, weak party identification and electoral manipulation.

Since the turn of the century, there has been a renewed interest in perceptions of democracy and the durability of authoritarianism (see Brownlee, 2007; Diamond,

Correspondence Address: School of Politics and International Relations, Australian National University, Canberra, ACT 0200, Australia. Email: juliet.pietsch@anu.edu.au

${ }^{\dagger}$ An earlier version was delivered at the 'Hybrid Regimes in Central and Eastern Europe and East and Southeast Asia' conference, Center for European Studies, The Australian National University, 16-17 August 2012. 
2002; Levitsky \& Way, 2010; 2012; Mainwaring, 2012; Schedler, 2006). To date, the literature on the extent of democracy and authoritarianism in Southeast Asia looks specifically at the performance of political institutions and their failure to match up to expectations of liberal democracy. In 2002, Larry Diamond observed that we are far from consensus about what constitutes a democracy. Indeed, many regimes in Southeast Asia, according to Diamond, are pseudodemocratic "in that the existence of formally democratic political institutions, such as multiparty electoral competition, masks (often, in part, to legitimate) the reality of authoritarian competition" (Diamond, 2002: 24). These types of regimes are sometimes referred to as hybrid regimes, electoral authoritarian regimes or competitive authoritarian regimes (see Levitsky \& Way, 2012; Schedler, 2006).

In this article, I argue that we need to look further afield to see what else could be underpinning the durability of authoritarianism. I suggest we look more closely at understandings and expectations of democracy. If over $90 \%$ of the population believe that their political system is a democracy (as is the case in Singapore and Vietnam), then there are very different understandings between East and West about (i) what democracy actually means and (ii) the expectations of democracy. Therefore, the focus of this article is on everyday perceptions of democracy among Southeast Asians. Three key questions underpin this research: First, why do some citizens perceive their regime as a democracy, while others do not? Second, why do some citizens rate their regime as a well-functioning democracy, while others do not? And third, why do some citizens perceive their regime as progressing towards democracy, while others do not? The answers to these questions will shed light on explaining the durability of authoritarianism in Southeast Asia and public opinion towards democracy.

In looking at these questions, it is argued that authoritarianism in Southeast Asia is not only sustained by strong state institutions (see Geddes, 1999; Levitsky \& Way, 2012) but also by public opinion, which reflects different understandings and expectations of democracy. For example, we find a very high proportion of Singaporeans report that their political system is a democracy, despite the authoritarian characteristics of Singaporean institutions and the long-held dominance of the People's Action Party (PAP). The case of Singapore is not uncommon in Southeast Asia. Indeed, we find a similar pattern in other single-party-dominated systems in the region including Malaysia, Cambodia and Vietnam. Does this mean that citizens in Southeast Asia who perceive their system to be a democracy, despite the lower standards of electoral competition, have different expectations of democracy? To explore this further, this article is organized in two sections: the first section compares the extent of democracy and authoritarianism in Southeast Asia in terms of regime performance. The second section explores the experience of democracy at the individual level by drawing on findings from the Asian Barometer (Wave 2).

\section{Democracy in Southeast Asia}

Typologies of democratic systems often distinguish types of democracy according to their position on a continuum between different principles of democracy. These 
principles are often divided into opposing pairs of democratic concepts such as liberty versus equality, small versus big government, pluralism versus the common good, individualism versus collectivism and so on (Thomassen, 2007). Fuchs and Klingemann (2002) observe that people in different parts of the world prefer different types of democracy, located along this continuum. In most cases, differing normative positions are provoked by tensions between the freedom of individuals on the one hand and the demands of the community on the other (Fuchs \& Klingemann, 2002: 24). From a minimalist perspective, Dahl offered an electoral procedural definition of a democratic electoral regime which should have elected officials, free, fair and frequent elections, inclusive suffrage and citizenship, freedom of expression, alternative sources of information and associational autonomy (Dahl, 1998: 84-91).

More recent research has shown that the connections between elections and democracy are less than clear-cut. Indeed, political science research has shown that there is a certain "threshold of competitiveness" in elections that must be achieved before a regime can be classified as a liberal democracy. For example, the fairness of elections needs to be measured by how much the electoral institutions are deemed independent (see Isaac, 2012: 863). Without competitive elections within an institutional environment that is free from government intervention, such regimes have been classified as hybrid regimes, electoral authoritarian or competitive authoritarian.

In terms of political transformation across Southeast Asia, Indonesia (a former authoritarian regime) stands out as having made substantial progress towards democracy and can perhaps be regarded as a leader in the region in this respect. Indonesia's authoritarian regime under President Suharto between 1966 and May 1998 was characterized by widespread poverty, military intervention, nepotism, corruption, dependency on foreign debt, financial crisis and economic collapse. Since then, Indonesia has made a number of significant improvements in the areas of economic reform, freedom of speech, inter-party competition and institutional reforms such as implementing one of the world's largest decentralization programmes. Finally, in 2009, Indonesia was classified as a liberal democracy. However, political scientists are still concerned about remaining authoritarian practices that are left over from the New Order period, particularly in relation to corruption (Mietzner \& Aspinall, 2010).

As in Indonesia, democracy in the Philippines has similarly made considerable improvements over time yet has disappointed expectations among the Philippine public, particularly in relation to better governance and poverty alleviation. In 1986, the authoritarian regime under President Ferdinand Marcos ended in the streets of Manila. Since then, according to Freedom House, the Philippines is classified as an "electoral democracy". However, alleged electoral fraud is continuing to undermine democratic progress in the Philippines. For example, the Arroyo presidency between 2001 and 2010 was marked by a series of mass protests, plunging popularity, clientelism within political parties, weakened rule of law, corruption scandals including allegations of rigging the 2004 Presidential vote and several coup attempts (see Quimpo, 2009; Thompson, 2010). 
Thailand has also had a somewhat turbulent experience with democracy. Reilly observes that Thailand has moved between competitive democracy, military rule and civilian quasi-democracy over the past decade (Reilly, 2013: 159). Between 2001 and 2005, Thaksin's Thai Rak Thai (TRT) party dominated Thai electoral politics. During this time, Thaksin merged four minority parties into TRT, which dominated the Senate. Economic growth expanded under Thaksin and he was then re-elected in 2005. According to Emmerson (2012: 70), "it took the corrupt and sometimes brutal tycoon Thaksin Shinawatra to instrumentalize Thai democracy" by transforming a democracy that had been largely indifferent to the rural poor and delivering welfare to millions of needy Thais. In 2006, Thaksin was toppled by a military coup and forced into exile. Since then, democracy has been characterized by lack of accountability and judicial independence. In terms of political party competition, apart from the Democrat Party, most political parties in Thailand tend to fade in and out without any strong ideological grounding.

Singapore and Malaysia are both lagging behind in terms of democratic progress. According to Diamond, "Singapore is the most economically developed non-democracy in the history of the world" (Diamond, 2012: 7). Since independence, Singapore has been governed by the PAP. While there are general elections, the PAP dominates parliamentary seats and strongly discourages anyone considering voting or running for other parties. In the 2011 parliamentary elections, while the PAP only won $60 \%$ of the vote they managed to win over $90 \%$ of parliamentary seats. The opposition remains a very long way from winning an election outright. Singapore's authoritarianism is accompanied by strong economic development, which depends to a large extent on low paid workers from neighbouring Southeast Asian countries. Foreign workers include Bangladeshi and Burmese construction workers and domestic helpers from Indonesia and the Philippines. While the PAP limits political freedoms, it is suggested that any opposition party would make a mess of the economy and its successful rapid GDP growth (Verweij \& Pelizzo, 2009).

Authoritarian measures to control elections are similarly practiced in Malaysia. Since independence in the 1950s, the ruling Barisan National (BN) coalition and its lead party United Malays National Organization (UMNO) has dominated Malaysian politics. The structure of the electoral system has traditionally given a more favourable outcome for the $\mathrm{BN}$ at general elections. For example, rural Malay strongholds have far lower numbers of voters per elected office holder compared to urban districts (see Arakaki, 2009; Freedman, 2006). But even with an electoral system in their favour, in the 2008 parliamentary general election, the BN secured only 140 out of 222 seats which were considered by many as a "disastrous" result for the BN coalition who are accustomed to securing a two-thirds majority in the Malaysian parliament.

Many have argued that the BN suffered significant losses ending its long-held twothirds majority in Parliament because of the cumulative effects of the politicization of ethnicity and religion, which favoured Malay Muslims over minority groups (Chinese and Indians). Some of this stems from Malaysia's poor treatment of Malaysian Indians, a number of whom in 2007 took to the streets protesting discrimination 
and the lack of job opportunities (Arakaki, 2009: 87). While the BN lost its two-thirds majority, the newly multi-ethnic People's Justice Party or PKR with a more centrist platform did very well winning 31 seats in 2008. The Pan-Malaysian Islamic Party or Parti Islam Se-Malaysia (PAS) with its new shift towards secular nationalism was also successful with 23 seats. The PAS emphasized the need for a good administration, Islamic education, rights for all races, women's dignity, human development and housing (Moten, 2009: 29). Like the PKR and the PAS, the Democratic Action Party (DAP) which gained 23 seats focused on respect for the rule of law, reduced corruption, equal opportunity, accountability, good governance and greater economic equality. A similar election result in 2013 showed a strengthening opposition. But even with a strengthening opposition, UMNO hegemony, political coercion and the marginalization of the Chinese community have all increased.

Vietnam and Laos have remained as one-party communist states with bans on the formation of opposition parties. While Cambodia made moves towards democracy in 1993, it is a long way from being regarded as one, with increasing levels of corruption and human rights violations. As former French colonies, Vietnam, Laos and Cambodia are often grouped together as Southeast Asia's most impoverished countries. While there is a growing tension between the middle class and the elite political culture, the middle classes are not overly supportive of dismantling the one-party system (Gainsborough, 2012). Reilly (2013) suggests that Vietnam, Laos and Cambodia are heavily integrated with China and perhaps this is one of the reasons why the political culture is fairly distinct from other countries further away from China's influence, particularly those situated off the mainland in Maritime Southeast Asia.

To this point, this article has looked at how regimes in Southeast Asia are progressing (or not progressing) at the institutional level in terms of economic and political performance. Such indicators of democracy represent the necessary institutional "hardware" of democracies (see Rose et al., 1998; Shin, 2015). From a political perspective, each country in the region has had a lengthy experience of authoritarianism and some countries more than others have managed to implement major political reforms, such as Indonesia and to a lesser extent the Philippines and Thailand. However, even in Indonesia, the Philippines and Thailand, there are a variety of different viewpoints on the extent of progress of democratization. Therefore, one way to find out how democracy is progressing in Southeast Asia is by asking citizens what they think about the political system and what democracy means to them. By looking at what citizens think, we can begin to examine whether citizens' satisfaction with democracy is consistent with progress (or lack of progress) being made at the institutional level (see Shin, 2015). According to Shin and Wells (2005), while there might be significant democratic progress at the institutional level, the political culture of the citizenry also needs to be transformed into a culture of democracy. Along the same line of argument, Chang et al. (2007) suggest that no democratic regime will last without legitimacy in the eyes of its own people. Therefore, in order for democracy to become long-lasting and stable, "the bulk of the citizenry must develop a deep and resilient commitment to it" (Chang et al., 2007: 66). 
In the next section, the analysis draws on data from the Asian Barometer Surveys (ABS) to explore, first, whether popular understandings of democracy are consistent with our understanding of the level of institutional performance in each country, as previously discussed. Second, I explore whether there is overall support for democracy in the region and finally whether citizens in Southeast Asia feel as if their country is progressing towards democracy despite expert opinion suggesting otherwise.

\section{Public Opinion Towards Democracy}

The ABS is a respected international survey, highly valued by social scientists in political science and Asian Studies. The survey (fielded between 2005 and 2007, depending on the country) contains a range of items measuring identity, media usage and mass political attitudes towards democratization and regional governance. The samples include 1000 respondents from each country, which allows for a crosssection of respondents from diverse cultural and socio-economic backgrounds. This section will draw on bivariate and multivariate analyses to examine public opinion towards democracy in Southeast Asia. The analysis begins by looking at public support for democracy across several countries in Southeast Asia.

Figure 1 shows the difference between those who report that their country is democratic and those who report that their country is not democratic. The findings show that in contrast to various indicators of democratic performance in Southeast Asia, the majority of respondents in Southeast Asia report that they live in a democracy. While Singapore is widely perceived as having a single-party-dominated system

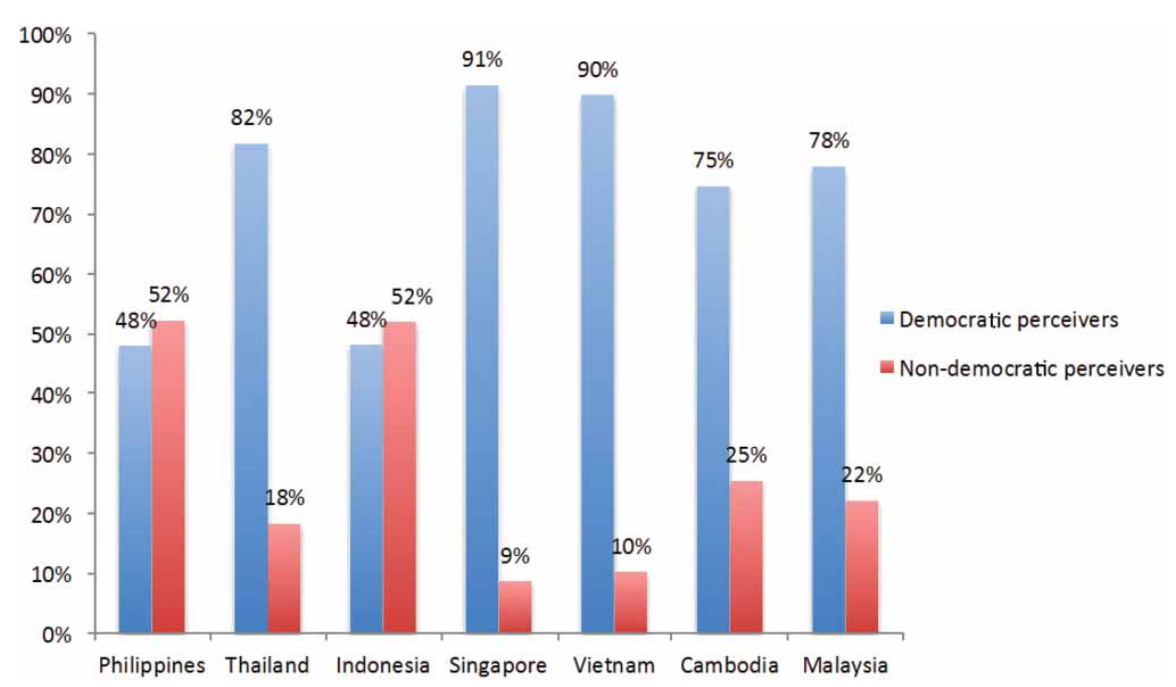

Figure 1. Difference between democratic perceivers and non-democratic perceivers, 2005-2007.

Source: Asian Barometer Surveys (2005-2008). 
with limited party competition and constraints on press freedom, up to $91 \%$ of Singaporeans report that their political system is a democracy. Similarly, in Vietnam, $90 \%$ of respondents state that their political system is a democracy and only $10 \%$ report that they do not live in a democracy. In the countries that are viewed as more democratic by experts, there is less confidence among the populations in the democratic nature of their political systems. For example, in Indonesia and the Philippines, less than half the population believe that their political system is a democracy. This could be explained by high levels of corruption in Indonesia and the Philippines, which undermines and perhaps overshadows any progress made in political reforms. There could also be a more sophisticated understanding of what is meant by true democracy in Indonesia and the Philippines, thus raising expectations among the general public.

The next stage of the analysis is to explore whether those who perceive their system is a democracy actually report that they live in a well-functioning democracy. The results in Table 1 show that over 8 in 10 democratic perceivers in Thailand, Singapore, Vietnam and Cambodia said that they live in a well-functioning democracy. The high proportion of the population believing that they live in a well-functioning democracy may in part be related to the fact that democracy is evaluated in terms of economic performance rather than in terms of electoral competition and other institutional indicators of democracy. In the period when the survey was conducted, real GDP growth between 2000 and 2007 increased by 5\% in Thailand, 6\% in Singapore, 8\% in Vietnam and 10\% in Cambodia. Interestingly, the Philippines and Indonesia also experienced growth rates of over 5\% (OECD, 2012). Yet, up to $45 \%$ of Filipino respondents and 23\% of Indonesian respondents said that they had a malfunctioning democracy. This is despite record improvements in economic growth over the last few decades.

The Asian Barometer asks respondents whether they believe the economy is more important, democracy is more important or both are equally important. Respondents are asked to separate their views of democracy as an abstract principle and the

Table 1. Attitudes towards democratic performance among democratic perceivers, 2005-2007

\begin{tabular}{lcccr}
\hline & $\begin{array}{c}\text { Malfunctioning } \\
\text { democracy }\end{array}$ & $\begin{array}{c}\text { Well-functioning } \\
\text { democracy }\end{array}$ & Total $(\%)$ & Total $(n)$ \\
\hline The Philippines & 44.9 & 55.1 & 100 & 541 \\
Thailand & 10.4 & 89.6 & 100 & 1179 \\
Indonesia & 23.1 & 76.9 & 100 & 655 \\
Singapore & 8.5 & 91.5 & 100 & 866 \\
Vietnam & 6.2 & 93.8 & 100 & 973 \\
Cambodia & 11.5 & 88.5 & 100 & 668 \\
Malaysia & 21.2 & 78.8 & 100 & 881 \\
\hline
\end{tabular}

Source: Asian Barometer Surveys (2005-2008). 
Table 2. Attitudes towards economic development and democracy, 2005-2007

\begin{tabular}{lccccr}
\hline & $\begin{array}{c}\text { Economy is more } \\
\text { important }\end{array}$ & $\begin{array}{c}\text { Democracy is } \\
\text { more important }\end{array}$ & $\begin{array}{c}\text { Both equally } \\
\text { important }\end{array}$ & Total (\%) & Total $(n)$ \\
\hline The Philippines & 72.5 & 21.2 & 6.3 & 100 & 1080 \\
Thailand & 46.7 & 22.8 & 30.5 & 100 & 1391 \\
Indonesia & 78.9 & 10.2 & 10.9 & 100 & 154 \\
Singapore & 67.8 & 11.7 & 20.5 & 100 & 963 \\
Vietnam & 54.4 & 23.2 & 22.3 & 100 & 1119 \\
Cambodia & 58.8 & 26.9 & 14.3 & 100 & 941 \\
Malaysia & 62.2 & 25.0 & 12.8 & 100 & 1167 \\
\hline
\end{tabular}

The question was, "If you had to choose between democracy and economic development, which would you choose?".

Source: Asian Barometer Surveys (2005-2008).

economy. The results shown in Table 2 suggest that the economy is on the whole more important in most countries compared to an ideal view of democracy. However, in some countries, the economy matters much more than democracy for respondents. For example, up to $73 \%$ of Filipino respondents report that the economy is important compared with only $47 \%$ of Thai respondents. In Thailand, the results are mixed with just over a third of the population stating that the economy and democracy are important. In Indonesia, the most successful democracy in the region, only $10 \%$ of the population report that democracy is more important than the economy, which suggests a wide discrepancy between progress made towards democracy in Indonesia in terms of political reforms and citizen orientations.

These findings are consistent with the thermostatic model of responsiveness, where citizens will adjust their preferences for more (less) policy in reaction to the policy itself, much like a thermostat (see Franklin \& Wlezien 1997; Johnson et al. 2005; Wlezien, 1995; Wlezien 2004). For example, citizens in less democratic countries will indicate an awareness of what they lack by rating democracy as more important than do citizens who already have it. On the whole, citizens in countries that are already classified as democracies have a very instrumental view of democracy. Economic performance and the capacity to provide health and welfare are rated more highly than the more abstract concept of democracy. This is related to the fact that public responsiveness is often conditional on the saliency of the issue. If democracy has been consolidated and is considered no longer salient, then citizens will not rank it as highly as other issues. Those giving more importance to democracy are those living in countries that are identified as least democratic. Those giving least importance to democracy are those living in countries whose institutions are the most democratic in the region even if (in the case of Singapore) the choices citizens have made have been consistently for the same party.

The next part of the analysis seeks to explain other factors that may shape whether or not people perceive their system to be a well-functioning democracy. In countries 
such as Indonesia, which transitioned relatively quickly to a democracy, one might expect citizens to feel somewhat disappointed with democratic progress if they believe democratization is moving too slowly. The findings in Table 3 show that there is a great deal of variation in perceptions of democratic progress. In Malaysia and Singapore, for instance, among those who perceive their country as a democracy, around 9 in 10 respondents regard their regime as not progressing at all towards democracy or "stalled". In Table 2, the results showed that up to 9 in 10 Singaporeans report that they live in a well-functioning democracy. However, in Table 3, a significant majority report that democratic progress has "stalled" indicating that perhaps the majority are relatively content with the current level of democracy in Singapore.

These results are perhaps not too surprising given the enduring authoritarian political culture in Malaysia and Singapore that has been a product of these countries power state apparatuses (see Slater, 2012). At the other end of the spectrum, 9 in 10 respondents in Cambodia report that their system is progressing towards democracy or "consolidating". This may have to do with the fact that Cambodians have suffered from decades of conflict and perhaps relatively speaking, Cambodians are in a much better position than before. However, this finding seems perplexing given the dominance of the Cambodian People's Party (CPP) in all three branches of government. Other issues which plague democratic progress in Cambodia include widespread corruption, lack of judicial independence and free and fair elections. Therefore, it is necessary to further try and explain why citizens throughout Southeast Asia are more or less likely to perceive their system as a democracy that is functioning well.

The argument thus far has alluded to the higher importance placed on governance rather than democracy as an ideal among Southeast Asians. Therefore, from here on I look at other aspects of governance, other than economic performance that may have an impact on citizen evaluations of democracy. To further understand some of the possible influences on public opinion towards democracy in Southeast Asia, a factor analysis was conducted of items in the Asian barometer that could explain public opinion towards democracy (see Table 2 in Appendix). Three clear domains of governance emerged from the factor analysis: (i) freedom and equality, (ii)

Table 3. Attitudes towards democratic progress among democratic perceivers, 2005-2007

\begin{tabular}{lcccc}
\hline & Consolidating & Stalled & Total $(\%)$ & Total $(n)$ \\
\hline The Philippines & 26.8 & 74.2 & 100 & 517 \\
Thailand & 62.6 & 38.4 & 100 & 835 \\
Indonesia & 36.7 & 63.3 & 100 & 626 \\
Singapore & 8.4 & 91.6 & 100 & 862 \\
Vietnam & 28.7 & 71.3 & 100 & 973 \\
Cambodia & 90.5 & 9.5 & 100 & 622 \\
Malaysia & 4.0 & 96.0 & 100 & 856 \\
\hline
\end{tabular}

Source: Asian Barometer Surveys (2005-2008). 
responsiveness and (iii) accountability. These factors explain almost two-thirds of the variance in the measures they summarize. Each domain is standardized between 0 and 10. Mean scores of governance domains are presented in Table 4. Included in that table are single item measures tapping political efficacy and political trust. These have been standardized so as to appear on the same scales as the other three factors.

In the final stage of the analysis, a binary logistic regression is conducted to examine the impact of particular domains on public opinion towards democracy. Public opinion towards democracy is measured in terms of whether or not respondents believe that they live in democracy (democratic experience), whether or not respondents believe that their democracy is functioning well (democratic performance) and whether or not respondents believe that the political regime in their country is progressing towards democracy (democratic progress). Throughout this analysis so far, results suggest that citizens in some countries in Southeast Asia are likely to evaluate democracy in terms of economic performance. Therefore, I also include attitudes towards the economy (economic conditions) and socio-economic background variables as controls. The results will indicate what aspects of governance have the strongest effect on public support for democracy in Southeast Asia.

The results in Table 5 reveal that in Southeast Asia, the governance domain of "responsiveness" is the most important determinant affecting "democratic experience" and "democratic performance". Those who believe that their country does well in these domains also report higher levels of democratic satisfaction in these terms. In terms of democratic progress, "freedom and equality" and "efficacy" are the most important determinants. In Southeast Asia, governments frequently tighten restrictions on press freedom and the right to gather and demonstrate. This is particularly the case in single-party-dominated systems such as Malaysia and Singapore. In the first part of this article, it was shown that in some countries democratic progress is undermined by the lack of free and fair elections and multiparty competition in these regimes. However, in these same countries where inter-party

Table 4. Mean scores of each domain

\begin{tabular}{lccccc}
\hline & $\begin{array}{c}\text { Freedom } \\
\text { and equality }\end{array}$ & Responsiveness & Accountability & Efficacy & $\begin{array}{c}\text { Political } \\
\text { trust }\end{array}$ \\
\cline { 2 - 6 } & Factor 1 & Factor 2 & Factor 3 & & \\
\hline The Philippines & 6.29 & 4.50 & 4.98 & 3.01 & 5.12 \\
Thailand & 6.87 & 4.70 & 4.58 & 6.75 & 6.37 \\
Indonesia & 7.02 & 5.08 & 5.42 & 4.26 & 6.11 \\
Singapore & 5.42 & 6.60 & 5.61 & 3.36 & na \\
Vietnam & 7.34 & 7.67 & 6.09 & 4.47 & 7.80 \\
Cambodia & 7.48 & 5.61 & 4.55 & 6.75 & 5.41 \\
Malaysia & 6.34 & 5.38 & 4.30 & 4.31 & 5.94 \\
\hline
\end{tabular}

Source: Asian Barometer Surveys (2005-2008). 
Table 5. Impact of domains on "Democratic experience", "Democratic performance" and "Democratic progress", controlling for background and materialist orientation (binary logistic regression)

\begin{tabular}{|c|c|c|c|c|c|c|}
\hline & \multicolumn{2}{|c|}{$\begin{array}{l}\text { Democratic } \\
\text { experience }\end{array}$} & \multicolumn{2}{|c|}{$\begin{array}{l}\text { Democratic } \\
\text { performance }\end{array}$} & \multicolumn{2}{|c|}{ Democratic progress } \\
\hline & $B$ & SE & $B$ & SE & $B$ & SE \\
\hline & \multicolumn{2}{|c|}{ Model 1} & \multicolumn{2}{|c|}{ Model 2} & \multicolumn{2}{|c|}{ Model 3} \\
\hline \multicolumn{7}{|l|}{ Domains } \\
\hline Freedom and equality & 0.99 & $0.19^{* * *}$ & 0.08 & $0.03^{* * *}$ & 0.15 & $0.02^{* * *}$ \\
\hline Responsiveness & 0.26 & $0.25^{* * *}$ & 0.25 & $0.03^{* * *}$ & -0.07 & 0.03 \\
\hline Accountability & 0.03 & $0.02^{*}$ & 0.08 & $0.02^{* * *}$ & 0.08 & $0.02^{* * *}$ \\
\hline Efficacy & 0.09 & $0.04^{*}$ & 0.04 & 0.06 & 0.21 & $0.05^{* * *}$ \\
\hline \multirow{2}{*}{\multicolumn{7}{|c|}{ Background controls }} \\
\hline & & & & & & \\
\hline Gender & -0.03 & 0.08 & 0.09 & 0.11 & 0.07 & 0.10 \\
\hline Urban & -0.00 & 0.08 & 0.05 & 0.12 & -0.66 & $0.11^{* * *}$ \\
\hline Age & -0.00 & 0.00 & 0.00 & 0.00 & -0.00 & 0.00 \\
\hline Education & 0.01 & 0.01 & -0.03 & $0.01^{*}$ & -0.06 & $0.01^{* * *}$ \\
\hline Income & -0.14 & $0.03^{* * *}$ & -0.01 & 0.05 & 0.27 & $0.04^{* * *}$ \\
\hline Christian & -0.00 & 0.09 & -0.63 & $0.14^{* * *}$ & 0.51 & $0.14^{* * *}$ \\
\hline Hindu & 1.71 & $0.35^{* * *}$ & -0.10 & 0.31 & -1.60 & $0.60^{* * *}$ \\
\hline Buddhist & 0.94 & $0.12^{* * *}$ & 0.80 & $0.18^{* * *}$ & 1.40 & $0.14^{* * *}$ \\
\hline Other & -0.30 & 0.23 & 0.31 & 0.46 & 0.00 & 0.36 \\
\hline None & 0.76 & $0.25^{* *}$ & 0.54 & 0.36 & -0.19 & 0.29 \\
\hline Economic conditions & -0.13 & 0.09 & 0.17 & 0.12 & 0.07 & 0.12 \\
\hline Constant & $-3.49^{*}$ & & $-2.74^{* * *}$ & & $-2.07^{* * *}$ & \\
\hline Nagelkerke $R^{2}$ & .23 & & .22 & & .25 & \\
\hline
\end{tabular}

SE, standard error.

Note: Democratic perceivers only in Model 2 and Model 3.

Source: Asian Barometer Surveys (2005-2008).

${ }^{*} p<.05$.

${ }^{* *} p<.01$.

$* * * p<.001$.

alternation in power is minimal or non-existent, support for democracy in these countries seemed to be relatively high. What matters most to respondents, according to results in Table 5 is whether or not citizens are free to speak, whether governments are responsive and accountable to their citizens and whether government is trustworthy. These domains are all considered more important than attitudes towards the economy in determining public opinion towards democracy in one's country. Overall, effects on the three domains are much as would have been expected from respondents who understood what it would take for their country to actually be a democracy or to be transitioning to one. This gives the impression that respondents to the Asia Barometer do know what it takes for a polity to be democratic. 
The results show that not only is good governance important but so is religion. The Muslim religion was chosen as a reference category. Muslims have often been targeted as less open to the ideals of liberal democracy. These findings reveal that Muslims were less likely to report that their political system is a democracy when compared with Buddhists, Hindus and those without a religion. Among those who are democratic perceivers, Muslim respondents are also less likely than Christians and Buddhists to believe that their democracy is performing well and that there is democratic progress. This is perhaps due to the fact that up to $57 \%$ of Muslim respondents in the pooled sample are from Indonesia, the largest Muslim country in the world. In Indonesia, even though there is a general consensus that the country is a democracy, there is less agreement about whether Indonesia's democratic system is characterized by good governance and accountability.

These findings suggest that Muslims in Southeast Asia are less likely than those who identify with other major religions to report that they live in a democracy. Among those who report their country is a democracy, they appear less satisfied with how well democracy is progressing compared to respondents from other major religions. This finding is consistent with the broader findings mentioned above. According to Emmerson, the legitimacy of democracy depends to a large extent on whether effective governance that delivers stability, legality and decent living standards can be achieved (Emmerson, 2004: 99). Given that Muslims in Indonesia, Malaysia, Thailand and the Philippines tend to be less financially well-off compared to other major religious groups, this could be one reason why there is more dissatisfaction expressed among Muslims. In support of this argument, these results also confirm that while those on lower incomes are more likely to report that they live in a democratic system they are less likely to believe that they have a well-functioning democracy that is progressing towards consolidation. Emmerson (2004) argues that in the case of Indonesia, concrete improvements in overall governance will matter more than abstract rights associated with democracy. There is some evidence for this in Table 2 but results in Table 5 also show that economic growth, while valued more than the abstract ideal of democracy is not a significant determinant of any of the factors democratic experience, democratic performance or democratic progress. Rather, what seems to matter more than anything else is the capacity to be free and lead a dignified life (see Ibrahim, 2006). A dignified life is one where people are free to speak without fear, have basic necessities and are treated as equals. When a government cannot be trusted to guarantee such universal protections, support for democracy may flounder.

\section{Conclusion}

This article has argued that at the institutional level, there are a number of important indicators that are used to quantitatively measure whether or not a country is considered a democracy. On the surface, it appears that economic growth is what matters most, especially in countries that are considered more democratic. However, when we include a range of other important measures of governance, we 
find that evaluations of democracy depend on the government's capacity to provide a fair and equal distribution of basic necessities across the whole of society, a place where citizens can protest without fear, fair and equal treatment of all religious and ethnic groups and a general level of responsiveness and accountability. While there is a great deal of variation within Southeast Asia as to whether or not people feel as if they live in a democracy and whether or not they have a well-functioning democracy, such variations depend on whether governments are able to provide good governance for all groups in society and overall expectations and experience of democracy in practice.

Evidence from this research suggests that many citizens in Southeast Asia tend to have an instrumentalist view of democracy that is measured according to governance outputs such as whether or not they have freedom from fear and freedom from want (in terms of being able to afford basic necessities). The vast majority of citizens in Southeast Asia considered the economy as more important than the abstract ideal of democracy. However, when the economy was incorporated into a regression analysis, it fell away as an important predictor of assessments of democracy in respondents' countries. What seems to matter most is good governance, particularly to those who are less economically privileged.

This leads to a general conclusion that if Southeast Asian countries are to be assessed not only according to whether elections are free and fair but also in terms of legitimacy in the eyes of its own peoples, democratic consolidation may still be a long way off. Authoritarian durability may continue to characterize Southeast Asia where, with the exception of Indonesia, elections are not free and fair and where in all countries, the majority tend to view democracy in instrumental terms rather than as an abstract ideal.

\section{Acknowledgement}

The author would like to sincerely thank Professor Doh Chull Shin from the University of California (Irvine), Professor Mark Franklin from the European University Institute and Massachussets Institute of Technology, Professor Donald Emmerson from Stanford University and the anonymous reviewers for their many helpful suggestions and comments.

\section{References}

Arakaki, R. (2009) The 2008 Malaysian election: the end of Malaysia's ethnic nationalism. Asian politics \& policy, 1(1), pp. 79-96.

Asian Barometer Surveys. (2005-2008). Asian Barometer (Wave 2). Taipei, Taiwan: Institute of Political Science, Academia Sinica and The Institute for the Advanced Studies of Humanities and Social Sciences, National Taiwan University.

Brownlee, J. (2007) Durable Authoritarianism in an Age of Democratization (New York: Cambridge University Press).

Chang, Y.-T., Zhu, Y.-H. \& Pak, C.-M. (2007) Authoritarian nostalgia in Asia. Journal of democracy, 18(3), pp. 66-80. 
Dahl, R.A. (1998) On Democracy (New Haven, CT: Yale University Press).

Diamond, L. (2002) Thinking about hybrid regimes. Journal of democracy, 13(2), pp. 21-35.

Diamond, L. (2012) The coming wave. Journal of democracy, 23(1), pp. 5-13.

Emmerson, D.K. (2004) Indonesia's approaching elections: a year of living dangerously? Journal of democracy, 15(1), pp. 94-108.

Emmerson, D.K. (2012) Minding the gap between democracy and governance. Journal of democracy, 23(2), pp. $62-73$.

Franklin, M. \& Wlezien, C. (1997) The responsive public: issue salience, policy change, and preferences for European unification. Journal of theoretical politics, 9, pp. 347-363.

Freedman, A. (2006) Political Change and Consolidation: Democracy's Rocky Road in Thailand, Indonesia, South Korea, and Malaysia (New York, NY: Palgrave Macmillan).

Fuchs, D. \& Klingemann, H.-D. (2002) Eastward enlargement of the European Union and the identity of Europe. West European politics, 25(2), pp. 19-54.

Gainsborough, M. (2012) Elites vs reform in Laos, Cambodia, and Vietnam. Journal of democracy, 23(2), pp. 34-46.

Geddes, B. (1999) What do we know about democratization after twenty years? Annual review of political science, 2(1), pp. 115-144.

Ibrahim, A. (2006) Universal values and Muslim democracy. Journal of democracy, 17(3), pp. 5-12.

Isaac, J. (2012) Authoritarianism, elections, democracy? Perspectives on politics, 10(4), pp. 863-869.

Johnson, M., Brace, P. \& Arceneaux, K. (2005) Public opinion and dynamic representation in the American states: the case of environmental attitude. Social science quarterly, 86(1), pp. 87-108.

Levitsky, S. \& Way, L. (2010) Competitive Authoritarianism: Hybrid Regimes after the Cold War (New York, NY: Cambridge University Press).

Levitsky, S. \& Way, L. (2012) Beyond patronage: violent struggle, ruling party cohesion, and authoritarian durability. Perspectives on politics, 10(4), pp. 869-891.

Mainwaring, S. (2012) From representative democracy to participatory competitive authoritarianism: Hugo Chavez and Venezuelan politics. Perspectives on Politics, 10(4), pp. 955-969.

Mietzner, M. \& Aspinall, E. (2010) Problems of democratisation in Indonesia: an overview, in: E. Aspinall \& M. Mietzner (eds) Problems of Democratisation in Indonesia: Elections, Institutions and Society (Singapore: Institute of Southeast Asian Studies), pp. 1-21.

Moten, R. (2009) 2008 general elections in Malaysia: democracy at work. Japanese journal of political science, $10(1)$, pp. 21-42.

OECD. (2012) Southeast Asia Economic Outlook Report, available at < http://www.guardian.co.uk/globaldevelopment/datablog/2012/nov/18/oecd-south-east-asia-economic-outlook $>$ (accessed 15 March 2013).

Quimpo, N.G. (2009) The Philippines: predatory regime, growing authoritarian features. The pacific review, 22(3), pp. 335-53.

Reilly, B. (2013) Southeast Asia: in the shadow of China. Journal of democracy, 24(1), pp. 156-164.

Rose, R., Mishler, W. \& Haerpfer, C. (1998) Democracy and its Alternatives (Baltimore: John Hopkins University Press).

Schedler, A. (2006) The logic of electoral authoritarianism, in: A. Schedler (ed.) Electoral Authoritarianism: the Dynamics of Unfree Competition (Boulder, CO: Lynne Rienner Publishers, Inc), pp. 1-23.

Shin, D. (2015) Cultural hybridization in East Asia: exploring an alternative to the global democratization thesis. Journal of elections, public opinion and parties, 25(1), pp. 10-30.

Shin, D.C. \& Wells, J. (2005) Is Democracy the only game in town? Journal of democracy, 16(2), pp. 88101.

Slater, D. (2012) Southeast Asia: strong-state democratization in Malaysia and Singapore. Journal of democracy, 23(2), pp. 19-33.

Thomassen, J. (2007) Democratic values, in: R. Dalton \& H.-D. Klingemann (eds) The Oxford Handbook of Political Behavior (Oxford: Oxford University Press), pp. 418-437. 
Thompson, M. (2010) Reformism vs populism in the Philippines. Journal of democracy, 21(4), pp. 154168.

Verweij, M. \& Pelizzo, R. (2009) Singapore: does authoritarianism pay? Journal of democracy, 20(2), pp. 18-32.

Wlezien, C. (1995) The public as thermostat: dynamics of preferences for spending. American journal of political science, 39(4), pp. 981-1000.

Wlezien, C. (2004) Patterns of representation: dynamics of public preferences and policy. Journal of politics, 66(1), pp. 1-24.

\section{Appendix}

Table A1. Variables, Scoring and Means

\begin{tabular}{|c|c|c|}
\hline Variable & Codes & Means \\
\hline Democratic experience & $\begin{array}{l}1=\text { democracy, } 0=\text { no } \\
\text { democratic experience }\end{array}$ & 0.72 \\
\hline Democratic performance & $\begin{aligned} 1 & =\text { well-functioning democracy, } 0 \\
& =\text { malfunctioning democracy }\end{aligned}$ & 0.84 \\
\hline Democratic progress & $1=$ consolidating, $0=$ stalled & 0.34 \\
\hline \multicolumn{3}{|l|}{ Freedom and equality } \\
\hline Free to speak without fear & $1=$ very low, $5=$ very high & 3.61 \\
\hline People have basic necessities & $1=$ very low, $5=$ very high & 4.08 \\
\hline $\begin{array}{l}\text { People can join an organization without } \\
\text { fear }\end{array}$ & $1=$ very low, $5=$ very high & 3.68 \\
\hline $\begin{array}{l}\text { Everyone is treated equally by } \\
\text { government }\end{array}$ & $1=$ very low, $5=$ very high & 3.37 \\
\hline \multicolumn{3}{|l|}{ Responsiveness } \\
\hline $\begin{array}{l}\text { Extent to which legislature can hold } \\
\text { government to account }\end{array}$ & $\begin{array}{l}1=\text { not responsive, } 4=\text { very } \\
\text { responsive }\end{array}$ & 2.88 \\
\hline $\begin{array}{l}\text { How often government officials abide by } \\
\text { the law }\end{array}$ & $\begin{array}{l}1=\text { not responsive, } 4=\text { very } \\
\text { responsive }\end{array}$ & 2.51 \\
\hline $\begin{array}{l}\text { How well do you think the government } \\
\text { responds to what people want? }\end{array}$ & $\begin{array}{l}1=\text { not responsive, } 4=\text { very } \\
\text { responsive }\end{array}$ & 2.61 \\
\hline \multicolumn{3}{|l|}{ Government accountability } \\
\hline $\begin{array}{l}\text { When the government breaks the laws, } \\
\text { there is nothing the legislature can do }\end{array}$ & $\begin{array}{l}1=\text { not accountable, } 5= \\
\text { accountable }\end{array}$ & 3.22 \\
\hline $\begin{array}{l}\text { Between the elections, there is no way of } \\
\text { holding the government to account }\end{array}$ & $\begin{array}{l}1=\text { not accountable, } 5= \\
\text { accountable }\end{array}$ & 2.85 \\
\hline \multicolumn{3}{|l|}{ Political efficacy } \\
\hline $\begin{array}{l}\text { People like me do not have any influence } \\
\text { over what government does }\end{array}$ & From $1=$ low to $4=$ high & 2.53 \\
\hline \multicolumn{3}{|l|}{ Political trust } \\
\hline $\begin{array}{l}\text { You can trust the government to do what } \\
\text { is right }\end{array}$ & From $1=$ low to $4=$ high & 2.42 \\
\hline
\end{tabular}


Table A1. (Continued)

\begin{tabular}{llr}
\hline Variable & \multicolumn{1}{c}{ Codes } & Means \\
\hline $\begin{array}{l}\text { Generally speaking you can trust the local } \\
\text { government officials }\end{array}$ & From $1=$ low to $4=$ high & 2.44 \\
$\begin{array}{l}\text { Gender } \\
\text { Urban/rural }\end{array}$ & $1=$ male, $0=$ female & 0.50 \\
Age & $1=$ urban, $0=$ rural & 0.49 \\
Education & in years & 41.36 \\
& $1=$ university education $0=$ no & 0.15 \\
Income & university education & 1.72 \\
Christian & Quintiles & 0.17 \\
Hindu & $1=$ Christian, $0=$ non-Christian & 0.28 \\
Buddhist & $1=$ Hindu, $0=$ non-Hindu \\
Muslim & $1=$ Buddhist, $0=$ non-Buddhist & 0.36 \\
Materialist orientation $(N)$ & $1=$ Muslim, $0=$ non-Muslim & 0.28 \\
& $1=$ Economy, $0=$ democracy & $(8,774)$ \\
\hline
\end{tabular}

Source: Asian Barometer Surveys (2005-2008).

Table A2. Factor Analysis of Domain Items

\begin{tabular}{|c|c|c|c|}
\hline & $\begin{array}{c}\text { Factor } \\
1\end{array}$ & $\begin{array}{l}\text { Factor } \\
2\end{array}$ & $\begin{array}{c}\text { Factor } \\
3\end{array}$ \\
\hline People are free to speak what they think without fear. & 0.786 & 0.110 & 0.233 \\
\hline People have basic necessities like food, clothes and shelter. & 0.746 & 0.080 & 0.035 \\
\hline People can join an organization they like without fear. & 0.742 & 0.098 & 0.309 \\
\hline Everyone is treated equally by the government. & 0.702 & 0.221 & -0.061 \\
\hline $\begin{array}{l}\text { To what extent is the legislature capable of keeping the } \\
\text { government in check? }\end{array}$ & 0.060 & 0.792 & 0.227 \\
\hline How often do national officials abide by the law? & 0.086 & 0.732 & 0.203 \\
\hline $\begin{array}{l}\text { How well do you think the government responds to what } \\
\text { people want? }\end{array}$ & 0.295 & 0.709 & -0.067 \\
\hline $\begin{array}{l}\text { When the government breaks the law there is nothing the } \\
\text { legal system can do. }\end{array}$ & 0.170 & 0.108 & 0.821 \\
\hline $\begin{array}{l}\text { Between elections, the people have no way of holding the } \\
\text { government responsible. }\end{array}$ & .089 & 0.181 & 0.812 \\
\hline Eigenvalue & 3.26 & 1.34 & 1.12 \\
\hline Variance explained (\%) & 36.26 & 14.99 & 12.40 \\
\hline Number of cases $(N)$ & & 2140 & \\
\hline
\end{tabular}

Source: Asian Barometer Surveys (2005-2008). 